\title{
Entrepreneurial Intentions of Pakistani Students: The Role of Entrepreneurial Education, Creativity Disposition, Invention Passion \& Passion for Founding
}

\author{
Temoor Anjum \& Sara Ravan Ramzani \\ Post Graduate Center, Limkokwing University of Creative Technology \\ Cyberjaya, Malaysia \\ Muhammad Farrukh \\ Faculty of Business and Management \\ Cyberjaya University of Medical Sciences, Cyberjaya, Malaysia \\ E-mail: mfarrukhiqbal@hotmail.com \\ Valliappan Raju, Nida Nazar \& Imran Ahmad Shahzad \\ Post Graduate Center, Limkokwing University of Creative Technology \\ Cyberjaya, Malaysia
}

Received: June 5, $2018 \quad$ Accepted: July 16, $2018 \quad$ Published: July 16, 2018

doi:10.5296/jmr.v10i3.13253 URL: https://doi.org/10.5296/jmr.v10i3.13253

\begin{abstract}
The purpose of this study was to investigate the impact of entrepreneurial education on entrepreneurial intentions of the university students, moreover, a mediating role of Entrepreneurial Passion, Perceived Creativity Disposition and Entrepreneurial Passion was also assessed. Data were collected from 595 university students; Partial least square technique was used with the help of SmartPLS software. Results of partial least square structural equation modeling showed that all the hypothesized direct and indirect relationship were supported. Possible implications for theory and practice are discussed in detailed.
\end{abstract}

Keywords: Entrepreneurship, Intention, disposition, Innovation passion, creativity. 


\section{Introduction}

Entrepreneurship has become a reckoning force in the world of business, it has provided a platform for new innovations and better ways to do things, it has also give rise to healthier competition in the business industry. Its key role in the economy of countries especially though the creation of jobs, increase in the level of employment as well as overall social and political growth (Farrukh, Khan, et al., 2017; Riaz, Farrukh, Rehman, \& Ishaque, 2016)) developed countries like USA, Germany and Japan owe their economic growth to the large population of entrepreneur (Prakash, Jain, \& Chauhan, 2015) who serve as a driving force on the development of these countries.

Entrepreneurship has been taken to mean many things all centered on profit making. Entrepreneurship involves independence, creativity, innovativeness, initiative and risk taking (Farrukh, Ying, \& Mansori, 2016).Essentially identifying opportunities is a trade mark for entrepreneurship with the intention of making moves on such an opportunity (Abu Haris \& Rahman, 2017; Fietze \& Boyd, 2017). Entrepreneurial intention (EI)is significant in understanding entrepreneurial process, it even precedes entrepreneurial behavior (Debarliev, Janeska-Iliev, Bozhinovska, \& Ilieva, 2015; Henley, Contreras, Espinosa, \& Barbosa, 2017).

Intention is the ultimate indicator of entrepreneurial behavior (Ajzen, 2005; Yusof, Jabar, Murad, \& Ortega, 2017). Collectively, intention can be perceived as a state of mind directing an individual's attention towards achieving a particular goal or objective (Vesalainen \& Pihkala, 1999), entrepreneurial intention on the other hand could be taken to mean individual participation or the intention to establish a business enterprise (Drennan \& Renfrow, 2005; Souitaris, Zerbinati, \& Al-Laham, 2007b, Fayolle \& Liñán, 2014). None the less, intention models reveal a fundamental and rational framework for achieving advanced knowledge in the field of entrepreneurial process (Krueger \& Carsrud, 1993). It is paramount to understand the factors that serve as the basis for creating entrepreneurial intention as it help to attain knowledge about entrepreneurial behavior (Shane \& Venkataraman, 2000).

The literature review has shown that the genesis of entrepreneurship is identification of opportunities, it has also stressed that the process has mandated the intention to display entrepreneurial behavior (Jemari et al., 2017).Entrepreneurial intention (EI) is the best way to explain the motive behind the rise of entrepreneurship among students as well as their decision to establish a capital driven business (Ariff et al., 2010). Hence, in the bid to develop policies and programs geared at promoting entrepreneurial behavior within students, there is the need to unearth the basic factors that has been accrued to shaping students intention to establish a new business (Lüthje \& Franke, 2003; Bakotić \& Kružić, 2010). Therefore, the explanation for the decision to become an entrepreneur or not is embosomed in the flair for creativity and creative thinking, thus, it is safe to say that entrepreneurship behavior is inherent in creative individuals (Farrukh, Chong, Mansori, \& Ravan Ramzani, 2017).

There are several studies backing up this assertion about creativity disposition (Batey \& Furnham, 2008). Individuals should be provided opportunities to judge their capability to generate new ideas that would contribute valuably to the achieving entrepreneurial goals and objectives. It is pivotal to note that the connection between entrepreneurial intention and 
creativity disposition cannot be successfully measured using intention-based models; this study thus seeks to examine the effect of individual student's creativity disposition on entrepreneurial intentions in Pakistani context.

Nevertheless, key factors such as good supporting environment and personality cannot be ruled out as an impulse to an individual's creative ability (Arrighetti, Caricati, Landini, \& Monacelli, 2016), therefore, enhancing creative ability is absolutely reliant on training (Cropley \& Cropley, 2000), the university can be taken as one of the important points to achieve ,this meaning that entrepreneurship education cannot be ruled out as a factor to a successful entrepreneur.

Entrepreneurship education could be taken to mean the effectiveness of this form of education as a key element through which practical knowledge about business, development skills, and self-confidence to which achieving business success is strictly tied to (Wilson et al., 2007). Making an effective entrepreneurship program available to a wide range of people can be expensive thus the need for the interference by universities and faculties so as to facilitate business creation by young and innovative individual graduates through support. This is quite challenging especially in developing world as strategies to establish to engender development and success of graduate entrepreneurs as well as providing suitable and supportive environments that would contribute to entrepreneurship growth generally (Nabi \& Liñán, 2011).

It is one thing to involve the tertiary institutions it is another to endeavor to make such strategy work. The incoherence between results of previous studies (Souitaris et al., 2007b; Dohse \& Walter, 2010; Byabashaija \& Katono, 2011; Lange et al., 2011; Hsiao et al., 2012; Lekoko et al., 2012) requires a more intensive research specifically in areas related to the connection between entrepreneurship intention and entrepreneurship education of students to substantiate the previous research works due to the need to determine how significant entrepreneurship education can be especially in the society (Peterman \& Kennedy, 2003; Albornoz \& Rocco, 2009).

The fact that there is limited researches in order to understand the relationship between entrepreneurship education and entrepreneurship intention in developing countries especially Asian developing economies (Nabi \& Liñán, 2011). Therefore there is a need to intensify the study to examine the relationship between entrepreneurship intention and entrepreneurship education in the future (Gaddam, 2008; Solesvik et al., 2012) however, the present study is consulted to examine the relationship between the recognized creativity disposition as well as overall entrepreneurial intention among university students and graduates to evaluate entrepreneurship according to the students' perception could make way for a valid assessment.

Without doubt, passion is pivotal in entrepreneurship (Bird, 1988; Cardon et al., 2013) it has the rudiments of cognitive, affective and behavioral elements (Chen et al., 2009), and has impacted in individual behavior (Cardon, Wincent, et al., 2009; Murnieks et al., 2011). There is therefore the need to develop passion tailored to establishing a venture because of its importance in achieving business success. Many researches on passion (Baum \& Locke, 2004; 
Chen et al., 2009) focused more on the relationship between individual entrepreneurial passion and its organizational results (Murnieks et al., 2011). Although studies have observed its indirect relationship trough observing the effect of passion as a mediator to other preceding factions to intention(De Clercq et al., 2011) or as precedence to other variables that have impacts on intention (Vallerand et al., 2007; Murnieks et al., 2011).

Therefore, this study scrutinizes the connection between entrepreneurial passion and entrepreneurial intentions. In the process of nurturing entrepreneurial passion, what is of utmost importance is providing solution to developmental problems by providing and inventing new products and establishing new organizations. Cardon et al., (2013), however only showed the levels of developing and validating the tools to arrest entrepreneurial passions and levels which are key contributors to these studies and did not proceed to examine the impacts of entrepreneurial passion on other probable studies or results.

In essence, this study examined the connection between effective entrepreneurship education and entrepreneurial intention with respect to the mediating roles creativity disposition and entrepreneurial passion.By doing so this study contributes to theory and practice. Theoretically, this study contributes to entrepreneruship literature by examining the mediating role of Creativity Disposition, Invention Passion \& passion for founding in entrepreneurial education and entreprenruial intention linkage.

Practically, stakeholders responsible for entrepreneurship development will have a better picture of how EI are formed and how potential venture initiators' beliefs and perceptions impact on their intention to commence a business. Overall, it enables government and policy makers to direct thought and resources on young adults who are likely to form entrepreneurial intentions, and consequently, create business ventures.

The paper unholds as follows, the next section of this manuscript discusses the hypothesis development which is followed by the methods and measures of the study.Next is data analysia and results and at the end this paper discusses the implication and contribution of the study.

\section{Hypothesis Development}

\section{Entrepreneurship Education and Entrepreneurial Intentions}

Creativity is viewed as creating something that is new and valuable (Amabile, 1996). It has also been perceived and accepted in this study as the combination of knowledge in the minds of the conscious minds of people, it allows and welcomes indulgent thinking in the creation of new ideas that are ground breaking and resourceful (Chen et al., 2013). Although Godfrey (1996) has considered that creativity is pivotal in the course of recreating businesses, he also opines that unleashing the vision of people thorough fun activities will be very helpful. He views innovation as significant in order to turn ideas into useful and valuable goods and services in the market. Creativity hence is the foundation of innovation (Almog-Bareket, 2011) and important to organizational growth. Consequently, creativity and innovation have been identified as chief factors for a successful long term business (Kerr \& Lloyd, 2008). 
To further buttress this point, Tepper and Kuh (2010) were of the opinion that creativity can be nurtured through training and developing skills, thus, effective entrepreneurship or enterprise education must be geared at developing enterprising skills (Pittaway et al., 2009b), the way to achieving enterprising skill is basically through creative thinking (Gibb, 2002a) which is why creativity development within students in business schools has become a matter that requires grave attention (Ghosh, 2014).

Another study by Matlay et al., (2011) indicated the role of entrepreneurship education in influencing students thinking and enquiry about business opportunities; this explains the role of creativity on the strength and acceptability of any business idea. DeTienne and Chandler (2004) were in support of identifying opportunities which they viewed as a skill that can be developed through the knowledge about entrepreneurship education. The study also indicated that this knowledge is capable of increasing the creative ideas and innovativeness. Similarly it is also revealed that creativity powerfully increased students, creative thinking. Supporting this view, Feng (2013) stressed that creativity education will accelerate the students ability to develop creating abilities that would result into a problem solving ability.

Significantly, it has been accepted owing to many theories and researches that certain targeted education could be responsible for developing a high level of self- confidence and self-efficacy in many individuals. For instance, the self-confidence exuded when people have the ability to carry out specific goals successfully has been alluded to social persuasion, modeling, judgment of an ones psychological state and mastery experience (Bandura, 1986), hence, entrepreneurship education is viewed as the force behind developing a person's self -efficacy. This is achieved by providing avenue to carry out researches and feasibility studies, developing business plans and participating in running a business venture. More so, platforms such as entrepreneurship educational programs where guest speakers and case studies are incorporated into training methods could help in developing self-efficacy this method can be referred as developing self-efficacy using models Wilson et al., 2007).this study proposed the following hypothesis:

\section{H2: Perceived effective entrepreneurship education is positively related to perceived creativity disposition.}

\section{Entrepreneurship Education and Entrepreneurial Passion}

The role of cognitive and behavioral factors in new business establishments is important which is why it should be adequately comprehended because of the chief role entrepreneurs' play in the creation of new ventures. Corbett (2005) had opined that in order to understand the nature of the entrepreneurial process, the method of individual learning and modes of acquiring knowledge that has effect on identifying opportunities and exploiting them should also be taken into consideration and properly grasped. Their role is embedded in the connection between knowledge, cognitive and creativity which shows that appreciating the distinct methods of individual learning adds value to entrepreneurship research. The study also shows the effect of learning perspective not only on gearing students to look into discovering new openings but developing the passion for looking into such opportunities which defined their identity as future entrepreneurs. 
Literature points to the fact that psychological characteristics affect individuals' entrepreneurial intention. Experiential learning methods can however be pivotal in changing emotional competences (Padilla-Meléndez et al., 2014). Learning and emotion are synonymous and often used together in this context as emotion is an essential factor in learning (Kyro, 2008). Thus entrepreneurship education should portray entrepreneurship as an emotionally intense process where there is a combination of excitement, anxiety and fear, as well as common experiences of lack of control high, uncertainty, and commitment, (Lackéus \& Williams Middleton, 2011). None the less, in order to comprehend emotion, used the terms "fun" ,"excitement", "buzz", and "passion" to explain emotion.

Supporting this view is Dey and Steyaert (2007) who countered the concept of knowledge that dismisses the connection between knowing and passion. Asides that, Lackéus and Williams Middleton (2011) pushed forward that action-based approach to learning portray emotion as critical in the venture creation process. More so, Padilla- Meléndez et al., (2014) proved that experiential learning techniques are vital strategies when trying to influence emotional competence and fueling entrepreneurial passion longer. Thus, in the context of entrepreneurship education, it can be surmised that the perception of effectiveness in entrepreneurship education could aid in fuelling entrepreneurial passion in people, which will automatically amount to performing the real entrepreneurial objective- establishment of ventures. This study comes to the following hypothesis:

H3: Perceived effective entrepreneurship education is positively related to entrepreneurial passion for inventing.

H4: Perceived effective entrepreneurship education is positively related to entrepreneurial passion for founding.

\section{Creativity and Entrepreneurial Intention}

Creativity is very synonymous to innovation. Creativity is dwelled upon in researches such as these because of its importance as a driving force in the development of the economies of many nations (Fritsch \& Sorgner, 2013). In 1970, Shackle introduced imagination and creativity in his research and tied it to entrepreneurship process, emphasizing that in any uncertain situation, all entrepreneurs employs his imagination to seek for the best possible solution. This argument also stresses the significance of imagination and creativity as mandatory skills in the bid to make business decisions as well as their influence in avoiding unpalatable consequences (Lourenço \& Jayawarna, 2011).

The explanation for people's choice of become an entrepreneur or not is reliant upon their ability to think creatively or opinion that they have the ability to be creative, which involves knowing the opportunities for inventing new and useful products and services or breaking form the norm and achieving new feats that is profitable, thus, the requirement for become a successful entrepreneur (Baron, 2004). Entrepreneurship has hence has been perceivedas a platform for creative individuals to achieve their business goals or objectives (Batchelor \& Burch, 2012). Creativity requires usefulness and resourcefulness, which are key to 
entrepreneurship development (Ward, 2004), Thus, creative individuals tend to have the will to take part in entrepreneurship behavior.

Hamidi, Wennberg, and Berglund (2008) made use of social cognitive theory to clearly show the need for weighing creativity in entrepreneurial intention- based models. The researchers are of the opinion that creativity disposition will build a huge amount ofconfidence that would probably yield expected outcomes of becoming an entrepreneur. In a similar study, Zampetakis, Gotsi, Andriopoulos, and Moustakis (2011) indicated that the more creative the students conceive they were, the higher their entrepreneurial intentions became. More so, Fatoki (2010) indicated, in the study of entrepreneurial intention among final year graduating students in South African, that creativity influenced and motivated entrepreneurial intention. Therefore, this study evaluated the relationship between entrepreneurial intentions and individual students' creativity disposition, which has been abandoned in several intention-based models (Hamidi et al., 2008). Thus, the following hypothesis was proposed.

\section{H5: Perceived creativity disposition is positively related to entrepreneurial intention.}

\section{Entrepreneurial Passion and Entrepreneurial Intentions}

"Love" or passion for something (Baum \& Locke, 2004), which connotes affective feelings, especially intense feelings that are positive (Cardon, Wincent, et al., 2009), has been noted in several ways by scholars, for instance, Vallerand et al., (2003) mentioned passion as an inclination that is strong towards a particular activity that is likeable, which they find significant, and in which they put is energy and time with agility. affective, cognitive, and behavioral components is also attached to motivational construct (Chen et al., 2009), as shown in the definition asserted by Vallerand et al., (2003) and the definition by Perttula (2003), where passion was defined as a psychological state enveloping positive and strong emotional arousal strong and internal force. Irrespective of this, other definition put emphasis on positive effects, for instance, Smilor (1997) termed passion as the vehement interest that comes to realization through the relentless pursuit of a, challenging, fulfilling and enriching purpose. These opinions are in line with performing an activity that is valuable (Chen et al., 2009). Passion, hence, is an impulse to people's behavior (Murnieks et al., 2011).

More so, scholars of entrepreneurship have termed entrepreneurship in a similar context, for instance, Baum and Locke (2004) emphasized that entrepreneurial passion fuels people's innate desire to partake in entrepreneurship allied activities. Cardon's et al., (2009) defined entrepreneurial passion as "consciously accessible, as well as intense positive feelings related to the entrepreneurial activities that are meaningful and salient to the self-identity of the entrepreneur". On the other hand, using social psychological and entrepreneurship literatures as a basis, Chen, Yao, and Kotha (2009) defined entrepreneurial passion as the over-emotional state of an entrepreneur achieved through cognitive and behavioral action which is very valuable. In recent times Murnieks et al., (2011) has defined entrepreneurial passion as a strong disposition towards important and meaningful activities allied to being self- employed. 
In a recent research, Cardon et al., (2013) carried out a number of empirical studies with the use of samples from chosen populations to validate and develop the tools responsible for entrepreneurial passion along with its dimensions. Their study showed entrepreneurial passion dimensions of positive feelings. The results also emphasized that a high percentage of entrepreneurial passion is joined with the relationship between the feelings and self-identity of an entrepreneur for each domain. However, taking the nature of the proposed sample among university students into consideration, this study stressed that the passion for establishing and inventing is more probable to be experienced and kept before to the main activity when still in school. Intention, therefore, becomes the main stand point.

Moreover, studies creating a direct connection between entrepreneurial passion and entrepreneurial intention which is conceived to immediately show entrepreneurial behavior (Krueger Jr et al., 2000) are difficult to trace. An example of the little exceptions is the study by Kickul, and Krueger (2005), who opined that entrepreneurial intensity, which is closely related to entrepreneurial passion, had been connected with purposes for intuitive, with more effect on the intentions of intuitive than analytics' intentions. This study, therefore, examined the relationship between entrepreneurial passion and entrepreneurial intentions. Hence, this study proposed the following hypotheses::

H6: Entrepreneurial passion for inventing is positively related to entrepreneurial intention.

H7: Entrepreneurial passion for founding is positively related to entrepreneurial intention.

\section{Perceived Creativity Disposition as a Mediator}

This study emphasized that creativity serves as a mediator in the relationship between entrepreneurial intention and effective entrepreneurship education. Godfrey (1996) argued that creativity is important in business continuity and reinvention and put forward the opinion that releasing imagination of people through fun activities. Historically it can be understood that educational process design has certain effects on the capabilities of individuals who perform innovative activities (Baumol, 2004) through making the analytical tools required for engaging in innovative related activities available for future entrepreneurs, as well as engendering creativity and imagination in an comprehensible manner . therefore, it generally agreed that creativity is a skill that can be acquired through learning (Runco, 2004) and can be taught through establishing support activities and supporting individuals(Williamson, 2001).

Tepper and Kuh (2011) emphasized that creativity can be nurtured through training and developing certain skills continually, they also explained in studying arts-degree programs are the best way to acquire such training as creativity skills are seriously cultivated in the field. Thus, effective entrepreneurship education is the best way to develop enterprising skills (Pittaway et al., 2009b) and the outmost tool for enterprising skill is creative thinking (Gibb, 2002a) which is why development of creativity among students in business schools is a priority (Ghosh, 2014).

However, indicating the central linkages, Lekoko, Rankhumise, and Ras (2012) were of the opinion that effective entrepreneurship education is significant in providing entrepreneurial 
skills and competencies for students, these things are expected to influence students' entrepreneurial intention. Karimi, Biemans, Lans, Mulder, and Chizari (2012) In another study used the TPB to examine the impact of entrepreneurship education programs (EEPs), since EEPs were discovered to significantly influence suggested behavioral control and subjective norms.

More so, Byabashaija and Katono (2011) conducted a study to observe any change in the attitudes and intentions of students at the closure of the entrepreneurship course. The change was little but considerable as well especially in attitudes.Thus, the results indicated lessons for policy makers and raised other areas of study for researchers, on matters such as effectiveness of such courses in entrepreneurship education and the tools that best explained its effectiveness on entrepreneurial intention. Consequently, this study had been geared at determining the mediating role of perceived creativity dispositions in the connection between entrepreneurial intention of students in the tertiary institutions and perceived effective entrepreneurship education, which would provide a valid assessment, leading to the study proposed the following hypothesis:

H8: Perceived creativity disposition mediates the relationship between perceived effective entrepreneurship education and entrepreneurial intention.

\section{Entrepreneurial Passion as a Mediator}

This study has also established that careful consideration of the formation of behavior and cognition would be needful in clarifying the complex levels of entrepreneurship (Baron, 2007). While Passion is a motivational construct with affective, cognitive, and behavioral components (Chen et al., 2009). It, also, influences people's behavior (Murnieks et al., 2011) and specially accounts for differences in entrepreneurial behavior.

Previous Studies have also emphasized that there is a connection between passion and learning activity engagement (Bonneville-Roussy et al., 2013). while activity engagement is taken to mean involvement in a designed educational activity that cultivates persistence in higher education (Kuh et al., 2008), entrepreneurial activity engagement, on the other hand is described as the result of entrepreneurial learning for individual student which is tangible, as well as emotional, because it gives rise to a feeling and a step toward performing real entrepreneurial activities and experiences (Pittaway et al., 2009a).

Therefore, it can be concluded, that the perception of effectiveness in entrepreneurship education is one of the important factors responsible for developing entrepreneurial passion in individuals, which invariably will lead to performing the activity (venture creation). Consequently, it is logical that passion precedes establishing ventures since it is necessary for entrepreneurship success. However, Cardon et al., (2013) proved that a high measure of entrepreneurial passion connects the relationship between the feelings and the centrality of the entrepreneur's self-identity since each domain of establishing, inventing, and developing. Based on the above arguments, this study states the following hypotheses:

H9: Entrepreneurial passion for inventing mediates the relationship between perceived effective entrepreneurship education and entrepreneurial intention. 
H10: Entrepreneurial passion for founding mediates the relationship between perceived effective entrepreneurship education and entrepreneurial intention.

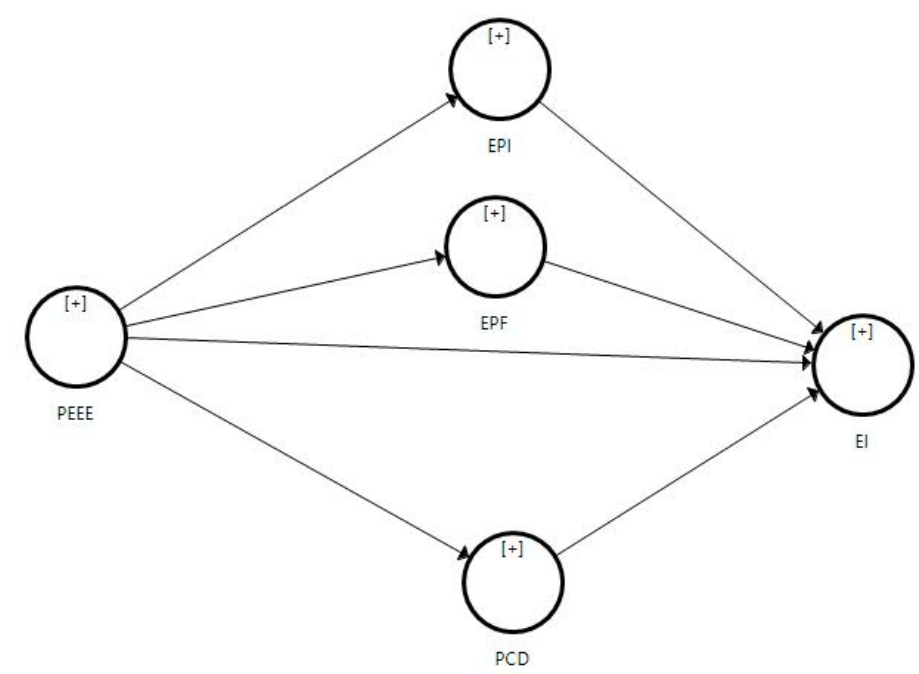

Figure 1. Model of the study

\section{Methods and measure}

This study adopted a deductive approach to build the hypothesis and quantitative technique was utilized to test the hypothesized model. Before conducting an actual study, a pilot test was run to check the validity and reliability of the measuring instrument, this was done by collecting data from 60 students. The results of pilot study showed that all the threshold values for reliability and validity were achieved. The target population of the study was student of two big universities located in Faisalabad, Pakistan. A total of 610 questionnaire were distributed out of which 556 questionnaires were collected back for data analysis.

The partial least squares (PLS) path modeling was employed to estimate the model and to test the relationships between the constructs. The items measuring the variables of the study were developed on a 7-point Likert scale with different anchors. Summary of the scales are given in table 1.

Table 1. Sources of Scales for alpha values

\begin{tabular}{|c|c|c|c|}
\hline Variables & Items & Sources & 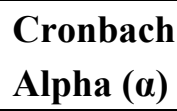 \\
\hline Entrepreneurial Intentions & 6 & Linãn and Chen (2009) & .78 to .95 \\
\hline Perceived effective Entrepreneurship Education & 5 & Souitaris et al., (2007) & 0.71 \\
\hline Entrepreneurial Passion for Inventing & 5 & Cardon et al., (2013) & 0.85 \\
\hline Entrepreneurial Passion for Founding & 4 & Cardon et al., (2013) & 0.72 \\
\hline Perceived Creativity Disposition & 8 & Zhou and George (2001) & 0.9 \\
\hline
\end{tabular}




\section{Results and Analysis}

PLS SEM has been utilized to produce the results. The Partial Least Squares technique is a powerful component-based method widely used in prior studies (Farrukh, Khan, et al., 2017; Farrukh, Chong, Mansori, \& Ravan Ramzani, 2017; Farrukh, Wei Ying, \& Abdallah Ahmed, 2016; Farrukh, Ying, \& Mansori, 2016, 2017; Riaz, Farrukh, Rehman, \& Ishaque, 2016; Shahzad, Farrukh, Kanwal, \& Sakib, 2018).

Table 2 represents the assessment of the measurement model and table 3 shows the results for the convergent validity.

\section{Assessment of Measurement Model}

This study used the sequential two-stage approach to assess the results (Hair et al., 2014). Henseler et al., (2009) explained that in the PLS-SEM analysis, the estimation of the outer model (i.e. measurement model) is first examined, checking the internal consistency reliability (i.e. composite reliability), convergent validity, and discriminant validity. Table 2 shows the results of measurement model evaluation. 
Table 2. Measurement Model evaluation-Quality Criteria

\begin{tabular}{|c|c|c|c|c|}
\hline \multirow{2}{*}{\multicolumn{2}{|c|}{ Construct Indicators }} & \multicolumn{3}{|c|}{ Composite } \\
\hline & & Loadings & Reliability & AVE \\
\hline \multicolumn{2}{|c|}{ Entrepreneurial Intention } & & 0.819 & 0.532 \\
\hline \multicolumn{2}{|c|}{ EI 1} & 0.763 & & \\
\hline \multicolumn{2}{|l|}{ EI 3} & 0.788 & & \\
\hline \multicolumn{2}{|l|}{ EI 4} & 0.639 & & \\
\hline \multicolumn{2}{|l|}{ EI 5} & 0.717 & & \\
\hline \multicolumn{2}{|c|}{ EI 1} & 0.763 & & \\
\hline \multicolumn{5}{|c|}{ Entrepreneurial Passion } \\
\hline \multicolumn{2}{|c|}{ Founding } & & 0.813 & 0.593 \\
\hline \multicolumn{2}{|l|}{ EPF1 } & 0.764 & & \\
\hline \multicolumn{2}{|l|}{ EPF2 } & 0.752 & & \\
\hline \multicolumn{2}{|l|}{ EPF3 } & 0.793 & & \\
\hline \multicolumn{5}{|c|}{ Entrepreneurial Passion } \\
\hline \multicolumn{3}{|c|}{ Inventing } & 0.742 & 0.581 \\
\hline \multicolumn{2}{|l|}{ EPI1 } & 0.784 & & \\
\hline \multicolumn{2}{|l|}{ EPI2 } & 0.814 & & \\
\hline \multicolumn{2}{|l|}{ EPI3 } & 0.769 & & \\
\hline \multicolumn{2}{|l|}{ EPI4 } & 0.867 & & \\
\hline \multicolumn{2}{|l|}{ EPI5 } & 0.748 & & \\
\hline \multicolumn{2}{|c|}{ Perceived Creativity Disposition } & & 0.765 & 0.521 \\
\hline \multicolumn{2}{|c|}{ PCD1 } & 0.738 & & \\
\hline \multicolumn{2}{|l|}{ PCD2 } & 0.727 & & \\
\hline \multicolumn{2}{|l|}{ PCD4 } & 0.816 & & \\
\hline \multicolumn{2}{|l|}{ PCD5 } & 0.885 & & \\
\hline \multicolumn{2}{|l|}{ PCD6 } & 0.655 & & \\
\hline \multicolumn{2}{|l|}{ PCD7 } & 0.778 & & \\
\hline \multicolumn{2}{|l|}{ PCD8 } & 0.763 & & \\
\hline \multicolumn{5}{|c|}{ Perceived $\quad$ Effective } \\
\hline Entrepreneurship & & & 0.851 & 0.531 \\
\hline PEEE1 & & 0.747 & & \\
\hline PEEE2 & & 0.772 & & \\
\hline PEEE3 & & 0.665 & & \\
\hline PEEE4 & & 0.718 & & \\
\hline PEEE5 & & 0.738 & & \\
\hline
\end{tabular}

\section{Discriminant Validity}

To test the discriminant validity we utilized Fornell-Larcker Criterion

\section{Discriminant Validity}

To test the discriminant validity we utilized Fornell-Larcker Criterion. 
Table 3. Discriminant Validity

\begin{tabular}{llllll}
\hline Construct & EI & EPF & EPI & PCD & PEEE \\
\hline EI & $\mathbf{0 . 7 2 9}$ & & & & \\
EPF & 0.343 & $\mathbf{0 . 7 7 0}$ & & & \\
EPI & 0.524 & 0.424 & $\mathbf{0 . 7 6 2}$ & $\mathbf{0 . 7 2 1}$ & \\
PCD & 0.331 & 0.520 & 0.274 & 0.282 & $\mathbf{0 . 7 2 8}$ \\
PEEE & 0.479 & 0.331 & 0.645 & & \\
\hline
\end{tabular}

Note: Diagonal elements (figures in bold) are the square root of the variance (AVE) shared between the constructs and their measures. Off diagonal elements are the correlations among constructs.

\section{Assessment of Structural Model (PLS-SEM)}

The major considerations for the assessment of the inner model were path coefficient estimates, coefficient of determination ( $\mathrm{R}^{2}$ values) (Hair et al., 2014). Results of path coefficients are given in table 4.

Table 4. Path Coefficients

\begin{tabular}{|c|c|c|c|c|}
\hline & $\begin{array}{l}\text { Original } \\
(\mathrm{O})\end{array}$ & Sample & T Statistics & $\begin{array}{l}\mathrm{P} \\
\text { Values }\end{array}$ \\
\hline $\mathrm{EPF}->\mathrm{EI}$ & 0.192 & & 2.489 & 0.000 \\
\hline EPI -> EI & 0.316 & & 4.272 & 0.000 \\
\hline PCD -> EI & 0.164 & & 2.223 & 0.026 \\
\hline PEEE -> EI & 0.172 & & 2.496 & 0.013 \\
\hline PEEE -> EPF & 0.347 & & 7.283 & 0.000 \\
\hline PEEE -> EPI & 0.644 & & 19.249 & 0.000 \\
\hline PEEE -> PCD & 0.269 & & 4.466 & 0.000 \\
\hline
\end{tabular}

Next is the examination of the coefficient of determination $\left(\mathrm{R}^{2}\right)$ of the endogenous latent variables (Henseler et al., 2009). Based on the threshold of acceptable values of $\mathrm{R}^{2}$, as proposed by Chin (1998), 0.19, 0.33, and 0.67. The results obtained showed that the $\mathrm{R}^{2}$ for the endogenous latent variables were $0.332,0.372,0.412$, and 0.220 for EI, PCD, EPI, and EPF respectively. 
This indicated that according to Chin (1998), the coefficients of determinations $\left(\mathrm{R}^{2}\right)$ in this study were all moderate. Overall, the $\mathrm{R}^{2}$ values obtained showed good predictive power of the exogenous latent variables on the endogenous latent variables. In other words, the amount of variance in the endogenous constructs, explained by the exogenous constructs, had been adequate. The following table 5 shows the coefficient of determination ( $\mathrm{R}^{2}$ values).

Table 5. Coefficients of determination $\left(\mathrm{R}^{2}\right)$

\begin{tabular}{lll}
\hline S/N & Construct & R Square $\left.\mathbf{( R}^{2}\right)$ \\
\hline 1 & EI & 0.332 \\
2 & PCD & 0.372 \\
3 & EPI & 0.412 \\
4 & EPF & 0.220 \\
\hline
\end{tabular}

\section{Test of Mediating Effects}

The mediating effect of PCD, EPI, EPF between PEEE and EI was subsequently examined by using multiple mediation technique as suggested by Hair et al (2017). Table 6 shows the results of Mediation analysis.

Table 6. Mediation Analysis

\begin{tabular}{llll}
\hline & Original Sample $(\mathrm{O})$ & T Statistics & P Values \\
\hline PEEE -> EPF -> EI & 0.232 & 2.445 & 0.048 \\
PEEE -> EPI -> EI & 0.204 & 4.065 & 0.000 \\
PEEE -> PCD -> EI & 0.044 & 2.023 & 0.043 \\
\hline
\end{tabular}

\section{Summary of findings}

The empirical findings showed that perceived effective entrepreneurship education had been significantly and positive related to EI. The findings indicated that perceived effective entrepreneurship education influenced the perceived creativity disposition of university students $(\beta=0.269)$. The results of the study confirmed that effective entrepreneurship education had an impact on both entrepreneurial passion for inventing and entrepreneurial passion for founding ( $\beta=0.644 ; \beta=0.347$ respectively). These relationships indicated that the perception of students about the effectiveness of the entrepreneurship education programme increased the students' passion for inventing and founding a business venture. This finding might be more effective if guest speakers with entrepreneurship success stories and role model entrepreneurs are employed to inspire students in the process of teaching entrepreneurship courses.

The results of the study supported the perceived creativity dispositions construct as a significant predictor of entrepreneurial intentions $(\beta=0.164)$. It showed that students, who felt that they possessed certain creative ability, would have a strong desire to behave entrepreneurially. 
The findings confirmed entrepreneurial passion for inventing and entrepreneurial passion for founding as significant predictors of entrepreneurial intentions among students $(\beta=0.316$; $\beta$ $=0.192$ respectively). These associations indicated that overall, entrepreneurial passion had been one of the major drivers of entrepreneurial intentions, thus, a high level of entrepreneurial passion is critically important in business creation and survival (Lackéus \& Williams Middleton, 2011).

The findings of the study confirmed the mediating role of perceived creativity disposition between perceived effective entrepreneurship education and entrepreneurial intention. The findings also confirmed the entrepreneurial passion for inventing and entrepreneurial passion for founding constructs as performing the mediating role between perceived effective entrepreneurship education and entrepreneurial intention.

\section{Contribution of the Study}

This study puts forward its contributions with respect to theory, methodology, and practice. Theoretically, this study moves towards the use of both TPB and SEE frameworks to bring forth useful information related to entrepreneurial intention and entrepreneurship education. Methodologically, this study employed hierarchical modeling using PLS in order to explain the relationships in its model.

Significantly, this will enable stakeholders responsible for entrepreneurship developments have a better picture of how EI are established and how potential venture initiators' perceptions affect their intention to establish a business. Potentially, it enables government and policy makers to include and young adults who are likely to form entrepreneurial intentions in their thoughts and plans of action, and thereby accelerating the creation of business ventures.

Practically, stakeholders responsible for entrepreneurship development will have a better picture of how EI are formed and how potential venture initiators' beliefs and perceptions impact on their intention to commence a business. Overall, it enables government and policy makers to direct thought and resources on young adults who are likely to form entrepreneurial intentions, and consequently, create business ventures.

\section{Theoretical Contribution}

This study has employed the use of both TPB and SEE frameworks in order to provide relevant information that will contribute to entrepreneurship education and entrepreneurial intention. More so, Krueger Jr et al., (2000), , suggested that the TPB is an important implement which allows educators to assess their training programs. Especially the study extends the existing intention theories in the relation to entrepreneurship by capturing students' perception of their own creativity ability and entrepreneurial passion in two dimensions (passion for founding and passion for inventing). Furthermore, it adds new finding to the theories by modeling the relationship between effective entrepreneurship education and two new outcomes constructs which is passion for inventing and passion for establishing that have not previously been investigated. 
Furthermore, the novelty it adds to the theories is also in their application in a new research setting (developing country), as researches on enterprise/entrepreneurship education and entrepreneurial intentions in developing countries are highly under researched (Nabi \& Liñán, 2011). Hence, the study strongly stresses that the proposed theoretical framework makes a significant contribution to knowledge in the context of entrepreneurship intentions.

Apart from that, empirical application of the SEE has shown that entrepreneurial intention can be accounted for by individuals driven by the perception of feasibility and desirability of entrepreneurial activity (Krueger \& Brazeal, 1994; Krueger jr et al., 2000; Fitzsimmons \& Douglas, 2011). Significantly, the inclusion of PEEE and PCD in particular has answered the call for more researches to consider factors that can highly contribute to the perceptions of feasibility (Krueger \& Brazeal, 1994).

The Shapero's entrepreneurial event theory also establishes firm creation as a result of the connection among contextual factors that could influence an individual's perceptions. Accordingly, Shapero and Sokol (1982) developed three stages in the venture creation process. The first is explained by displacements, which could positively or negatively influence an individual to pursue entrepreneurship. The other stage is the move the motion to be an entrepreneur because of the presence of some circumstances (i.e. training, environment, and family). In the last stage, the prospective entrepreneur will decide to establish a business when certain conditions are attained, for example, access to finance, supporting activities and human resources amongst others and hence, framing the perception of university support in this study model to interact with PEEE to increase PCD and entrepreneurial passion has considerably supported the theory.

Another view that is closely connected to the perceived behavioral control in TPB and seen as feasibility in SEE is the perceived entrepreneurial skills. When an individual has a good confidence in his skill in undertaking an entrepreneurial activity, he is motivated to develop entrepreneurial intention.

\section{Practical Contribution}

This study establishes several important practical contributions; in line with the antecedents of entrepreneurial intentions among Pakistani university students, with consideration to all stakeholders' responsible for entrepreneurship development to have a better picture of how EI is formed and how potential venture initiators' beliefs and perceptions have an impact on their intention to commence business. The study shows the role of entrepreneurship education in influencing individual personality trait to increase entrepreneurial intention of the program is made effective.

This study also engenders universities to take charge in various capacities in order to contribute to the achievement of the goal of initiating and encouraging business start-up by young graduates. Thus, some scholars have indicated that the challenges for the developing world are to develop graduate entrepreneurs and to provide suitable and supportive environments that will contribute to the growth of entrepreneurship (Nabi \& Liñán, 2011). However, the findings of this study provided certain clues that can be used to develop 
entrepreneurship education in the future; (1) it showed the need for educators and stake holders to design training programs and platforms that would help in developing skills necessary for business start-up, (2) to introduce platforms that have embedded creativity-enhancing technique that will make the overall process easy, and (3) to introduce effective learning contents with practical reality since it is capable of affecting students' entrepreneurial intentions through the development of creative ability.

In addition, via entrepreneurship education, educators could increase the possibility of students showing strong entrepreneurial passion if the students' are made to recognise that entrepreneurial opportunities exist in diverse areas and disciplines, as well as in encouraging them to consider the areas and disciplines they are most interested in, and then, developing exercises to explore entrepreneurial opportunities in those areas. Furthermore, role models could be employed to give motivational talks that will inspire students and build their passion towards entrepreneurship (Cardon et al., 2005; Cardon, Sudek, et al., 2009). Furthermore, university environment could create specific conditions to trigger students' creativity disposition and entrepreneurial passion, especially in recognizing how these important factors can increase students' intentions to consider entrepreneurship as a career option.

Finally, this study should be of interest to the groups of researchers, teachers, and supporters of entrepreneurship because it clarifies the interplay between the underexplored concepts of the effectiveness of entrepreneurship education, perceived creativity disposition, entrepreneurial passion for inventing and founding, as well as the perception of university support in the formation of overall entrepreneurial intention. It is also hoped that this study would guide further researches into exploring the interplay of personality traits and environmental conditions in enhancing entrepreneurship.

\section{References}

Abu Haris, N., \& Rahman, F. A. (2017). A study on application of fuzzy methods in entrepreneurship domain. INTERNATIONAL JOURNAL OF ADVANCED AND APPLIED SCIENCES, 4(12), 206-211. https://doi.org/10.21833/ijaas.2017.012.036

Ajzen, I. (1991). The theory of planned behavior. Organizational behavior and human decision processes, 50, 179-211. https://doi.org/10.1016/0749-5978(91)90020-T

Ajzen, I. (2005). Attitudes, personality, and behavior. McGraw-Hill Education (UK).

Albornoz, C., \& Rocco, T. S. (2009). Revisiting Entrepreneurship Education Literature: Implications for Learning and Teaching Entrepreneurship. COERC 2009, 2.

Almog-Bareket, G. (2011). The missing component in MBA programs. Management Decision, 49(10), 1600-1611. https://doi.org/10.1108/00251741111183771

Amabile, T. M. (1996). Creativity and innovation in organizations: Harvard Business School.

Arendt, S., \& Brettel, M. (2010). Understanding the influence of corporate social responsibility on corporate identity, image, and firm performance. Management Decision, 48, 1469-1492. https://doi.org/10.1108/00251741011090289 
Ariff, A. H. M., Bidin, Z., Sharif, Z., \& Ahmad, A. (2010). Predicting entrepreneurship intention among Malay University Accounting students in Malaysia. UNIFAR e- journal, $6(1)$.

Arrighetti, A., Caricati, L., Landini, F., \& Monacelli, N. (2016). Entrepreneurial intention in the time of crisis: a field study. International Journal of Entrepreneurial Behavior \& Research, 22(6), 835-859. https://doi.org/10.1108/IJEBR-12-2015-0326

Bakotić, D., \& Kružić, D. (2010). Students' perceptions and intentions towards entrepreneurship: The empirical findings from Croatia. izlazi u samo elektroničkom izdanju: NE.

Baron, R. A. (2004). The cognitive perspective: A valuable tool for answering entrepreneurship's basic "why" questions. Journal of Business Venturing, 19, 221- 239. https://doi.org/10.1016/S0883-9026(03)00008-9

Batchelor, J. H., \& Burch, G. F. (2012). Creative Individuals and Entrepreneurship: Is There an Inherent Attraction? Small Business Institute ${ }^{\circledR}$ Journal, 8(2), 1-11.

Batey, M., \& Furnham, A. (2008). The relationship between measures of creativity and schizotypy. Personality and Individual Differences, 45, 816-821. https://doi.org/10.1016/j.paid.2008.08.014

Baum, J. R., \& Locke, E. A. (2004). The relationship of entrepreneurial traits, skill, and motivation to subsequent venture growth. Journal of Applied Psychology, 89, 587- 598. https://doi.org/10.1037/0021-9010.89.4.587

Bird, B. (1988). Implementing entrepreneurial ideas: The case for intention. Academy of management Review, 13, 442-453. https://doi.org/10.5465/amr.1988.4306970

Bonneville-Roussy, A., Vallerand, R. J., \& Bouffard, T. (2013). The roles of autonomy support and harmonious and obsessive passions in educational persistence. Learning and Individual Differences, 24, 22-31. https://doi.org/10.1016/j.lindif.2012.12.015

Bruyat, C., \& Julien, P.-A. (2001). Defining the field of research in entrepreneurship. Journal of Business Venturing, 16, 165-180. https://doi.org/10.1016/S0883-9026(99)00043-9

Byabashaija, W., \& Katono, I. (2011). The impact of college entrepreneurial education on entrepreneurial attitudes and intention to start a business in Uganda. Journal of Developmental Entrepreneurship, 16, 127-144. https://doi.org/10.1142/S1084946711001768

Cardon, M. S., Gregoire, D. A., Stevens, C. E., \& Patel, P. C. (2013). Measuring entrepreneurial passion: Conceptual foundations and scale validation. Journal of Business Venturing, 28, 373-396. https://doi.org/10.1016/j.jbusvent.2012.03.003

Cardon, M. S., Sudek, R., \& Mitteness, C. (2009). The impact of perceived entrepreneurial passion on angel investing. Frontiers of entrepreneurship research, 29(2), 1. 
Cardon, M. S., Wincent, J., Singh, J., \& Drnovsek, M. (2009). The nature and experience of entrepreneurial passion. Academy of management Review, 34, 511-532. https://doi.org/10.5465/amr.2009.40633190

Chen, A., Li, L., Li, X., Zhang, J., \& Dong, L. (2013). Study on Innovation Capability of College Students Based on Extenics and Theory of Creativity. Procedia Computer Science, 17, 1194-1201. https://doi.org/10.1016/j.procs.2013.05.152

Chen, X.-P., Yao, X., \& Kotha, S. (2009). Entrepreneur passion and preparedness in business plan presentations: A persuasion analysis of venture capitalists' funding decisions. Academy of Management journal, 52, 199-214. https://doi.org/10.5465/amj.2009.36462018

Chin, W. W. (1998). The partial least squares approach to structural equation modeling. In G. A. Marcoulides (Ed.), Modern methods for business research (pp. 295-336). Mahwah, NJ: Lawrence Erlbaum Associates.

Corbett, A. C. (2005). Experiential learning within the process of opportunity identification and exploitation. Entrepreneurship Theory and Practice, 29(4), 473- 491. https://doi.org/10.1111/j.1540-6520.2005.00094.x

Cropley, D. H., \& Cropley, A. J. (2000). Fostering creativity in engineering undergraduates. High ability studies, 11, 207-219. https://doi.org/10.1080/13598130020001223

De Clercq, D., Casta-er, X., \& Belausteguigoitia, I. (2011). Entrepreneurial initiative selling within organizations: Towards a more comprehensive motivational framework. Journal of Management Studies, 48, 1269-1290. https://doi.org/10.1111/j.1467-6486.2010.00999.x

Debarliev, S., Janeska-Iliev, A., Bozhinovska, T., \& Ilieva, V. (2015). Antecedents of entrepreneurial intention: Evidence from Republic of Macedonia. Business and Economic Horizons, 11(3), 143-161. https://doi.org/10.15208/beh.2015.11

DeTienne, D. R., \& Chandler, G. N. (2004). Opportunity identification and its role in the entrepreneurial classroom: A pedagogical approach and empirical test. Academy of $\begin{array}{lllll}\text { Management } \quad \text { Learning } \quad \text { Education, } & 3,\end{array}$ https://doi.org/10.5465/amle.2004.14242103

Dey, P., \& Steyaert, C. (2007). The troubadours of knowledge: Passion and invention in management $\quad$ education. $\quad$ Organization, $14(3), \quad$ 437-461. https://doi.org/10.1177/1350508407076153

Dohse, D., \& Walter, S. G. (2010). The role of entrepreneurship education and regional context in forming entrepreneurial intentions: Working Papers 2010/18, Institut d'Economia de Barcelona (IEB).

Drennan, J. K. J., \& Renfrow, P. (2005). Impact of childhood experiences on the development of entrepreneurial intentions. International Journal of Entrepreneurship \& Innovation, 6, 231-238. https://doi.org/10.5367/000000005775179801 
Farrukh, M., Chong, W. Y., Mansori, S., \& Ravan Ramzani, S. (2017). Intrapreneurial behaviour: the role of organizational commitment. World Journal of Entrepreneurship, Management and Sustainable Development, 13(3), 243-256. https://doi.org/10.1108/WJEMSD-03-2017-0016

Farrukh, M., Khan, A. A., Khan, A. A., Shahid Khan, M., Shahid Khan, M., Ravan Ramzani, S., ... Soladoye, B. S. A. (2017). Entrepreneurial intentions: the role of family factors, personality traits and self-efficacy. World Journal of Entrepreneurship, Management and Sustainable Development, 13(4), 303-317.

https://doi.org/10.1108/WJEMSD-03-2017-0018

Farrukh, M., Wei Ying, C., \& Abdallah Ahmed, N. O. (2016). Organizational commitment: Does religiosity matter? Cogent Business \& Management, 3(1), 1-10. https://doi.org/10.1080/23311975.2016.1239300

Farrukh, M., Ying, C. W., \& Mansori, S. (2017). Organizational commitment: an empirical analysis of personality traits. Journal of Work-Applied Management, 9(1), 18-34. https://doi.org/10.1108/JWAM-12-2016-0026

Farrukh, M., Ying, C., \& Mansori, S. (2016). Intrapreneurial behavior: an empirical investigation of personality traits Research issue. Management \& Marketing. Challenges for the Knowledge Society, 11(4), 597-609. https://doi.org/10.1515/mmcks-2016-0018.

Fatoki, O. O. (2010). Graduate entrepreneurial intention in South Africa: motivations and obstacles. International Journal of Business and Management, 5(9), 87-98.

Fayolle, A., \& Li-án, F. (2014). The future of research on entrepreneurial intentions. Journal of Business Research, 67(5), 663-666. https://doi.org/10.1016/j.jbusres.2013.11.024

Feng, H.-Y. (2013). A Case Study on Creativity, Innovation and Entrepreneurship Education of the University in Taiwan. Paper presented at the Active Citizenship by Knowledge Management \& Innovation: Proceedings of the Management, Knowledge and Learning International Conference 2013.

Fietze, B., \& Boyd, B. (2017). Entrepreneurial intention of Danish students: A correspondence analysis Introduction. International Journal of Entrepreneurial Behavior \& Research, 23(4). https://doi.org/10.1108/MRR-09-2015-0216

Fitzsimmons, J. R., \& Douglas, E. J. (2011). Interaction between feasibility and desirability in the formation of entrepreneurial intentions. Journal of Business Venturing, 26, 431-440. https://doi.org/10.1016/j.jbusvent.2010.01.001

Fritsch, M., \& Sorgner, A. (2013). Entrepreneurship and creative professions: A micro- level analysis: SOEP papers on Multidisciplinary Panel Data Research.

Gaddam, S. (2008). Identifying the Relayionship Between Behavioral Motives and Entrepreneurial Intentions: An Empirical Study Based Participations of Business Management Students. The Icfaian Journal of Management Research. 7, 35, 5. 
Gámez-González, J., Rondan-Catalu-a, F. J., Diez-de Castro, E. C., \& Navarro-Garcia, A., (2010). Toward an international code of franchising. Management Decision, 48, 1568-1595. https://doi.org/10.1108/00251741011090333

Ghosh, K. (2014). Creativity in Business Schools: Towards a Need Based Developmental Approach. Global Journal of Flexible Systems Management, 15(2), 169-178. https://doi.org/10.1007/s40171-013-0049-2

Gibb, A. (2002a). In pursuit of a new 'enterprise'and 'entrepreneurship'paradigm for learning: creative destruction, new values, new ways of doing things and new combinations of knowledge. International Journal of Management Reviews, 4, 233- 269. https://doi.org/10.1111/1468-2370.00086

Godfrey, A. B. (1996). Creativity, innovation and quality. Quality Digest, 16(12), 17.

Hair Jr, J., Sarstedt, M., Hopkins, L., \& G. Kuppelwieser, V. (2014). Partial least squares structural equation modeling (PLS-SEM) An emerging tool in business research. European Business Review, 26(2), 106-121. https://doi.org/10.1108/EBR-10-2013-0128

Hamidi, D. Y., Wennberg, K., \& Berglund, H. (2008). Creativity in entrepreneurship education. Journal of Small Business and Enterprise Development, 15, 304-320. https://doi.org/10.1108/14626000810871691

Henley, A., Contreras, F., Espinosa, J. C., \& Barbosa, D. (2017). Entrepreneurial intentions of Colombian business students Planned behaviour, leadership skills and social. International Journal of Entrepreneurial Behavior \& Research, IJEBR-01-2017-0031. https://doi.org/10.1108/IJEBR-01-2017-0031

Henseler, J., Ringle, C. M., \& Sinkovics, R. R. (2009). The use of partial least squares path modeling in international marketing. Advances in International Marketing (AIM), 20, 277-320. https://doi.org/10.1108/S1474-7979(2009)0000020014

Hsiao, H.-C., Chen, S.-C., Chou, C.-M., Chang, J.-C., \& Jing, L.-L. (2012). Is Entrepreneurial Education Available for Graduates. African Journal of Business Management, 6, 5193-5200. International journal of business and globalisation, 2(1), 39-55.

Jemari, M. A., Kasuma, J., Kamaruddin, H. M., Tama, H. A., Morshidi, I., \& Suria, K. (2017). Relationship between human capital and social capital towards social entrepreneurial intention among the public university students. INTERNATIONAL JOURNAL OF ADVANCED AND APPLIED SCIENCES, 4(12), 179-184. https://doi.org/10.21833/ijaas.2017.012.032

Karimi, S., Biemans, H., Lans, T., Mulder, M., \& Chizari, M. (2012). The role of entrepreneurship education in developing students' entrepreneurial intentions. Available at SSRN 2152944. https://doi.org/10.2139/ssrn.2152944

Kerr, C., \& Lloyd, C. (2008). Pedagogical learnings for management education: Developing creativity and innovation. Journal of Management and Organization, 14(5), 486-503. https://doi.org/10.1017/S1833367200002996 
Kickul, J., \& Krueger, N. (2005). Toward a new model of intentions: The complexity of gender, cognitive style, culture, social norms, and intensity on the pathway to entrepreneurship: Center for Gender in Organizations, Simmons School of Management, Working Paper no. 20.

Krueger Jr, N. F., Reilly, M. D., \& Carsrud, A. L. (2000). Competing models of entrepreneurial intentions. Journal of Business Venturing, 15, 411-432. https://doi.org/10.1016/S0883-9026(98)00033-0

Krueger, N. F., \& Brazeal, D. V. (1994). Entrepreneurial potential and potential entrepreneurs. $\begin{array}{llll}\text { Entrepreneurship Theory and } \quad \text { Practice, } & \text { 91-91. }\end{array}$ https://doi.org/10.1177/104225879401800307

Krueger, N. F., \& Carsrud, A. L. (1993). Entrepreneurial intentions: Applying the theory of planned behaviour. Entrepreneurship \& Regional Development, 5, 315-330. https://doi.org/10.1080/08985629300000020

Kuh, G. D., Cruce, T. M., Shoup, R., Kinzie, J., \& Gonyea, R. M. (2008). Unmasking the effects of student engagement on first-year college grades and persistence. The Journal of Higher Education, 79(5), 540-563. https://doi.org/10.1080/00221546.2008.11772116

Kyro, P. (2008). A theoretical framework for teaching and learning entrepreneurship.

Lackéus, M., \& Williams Middleton, K. (2011). Venture Creation Programs: entrepreneurial education through real-life content. Paper presented at the interactive paper session BCERC 2011 conference, Syracuse.

Lange, J. E., Marram, E., Jawahar, A. S., Yong, W., \& Bygrave, W. (2011). Does an entrepreneurship education have lasting value? A study of careers of 4,000 alumni. Frontiers of entrepreneurship research, 31(6), 2.

Lekoko, M., Rankhumise, E., \& Ras, P. (2012). The effectiveness of entrepreneurship education: What matters most? African Journal of Business Management, 6, 12023-12033. https://doi.org/10.5897/AJBMx12.001

Lin, E., Lin, T. M., \& Lin, B.-W. (2010). New high-tech venturing as process of resource accumulation. Management Decision, 48, 1230-1246. https://doi.org/10.1108/00251741011076762

Li-án, F., Rodríguez-Cohard, J. C., \& Rueda-Cantuche, J. M. (2011). Factors affecting entrepreneurial intention levels: a role for education. International Entrepreneurship and Management Journal, 7, 195-218. https://doi.org/10.1007/s11365-010-0154-z

Lourenço, F., \& Jayawarna, D. (2011). Enterprise education: Tthe effect of creativity on training outcomes. International Journal of Entrepreneurial Behaviour \& Research, 17, 224-244. https://doi.org/10.1108/13552551111130691

Lüthje, C., \& Franke, N. (2003). The 'making'of an entrepreneur: testing a model of entrepreneurial intent among engineering students at MIT. R\&d Management, 33, 135-147. 
https://doi.org/10.1111/1467-9310.00288

Matlay, H., Heinonen, J., Hytti, U., \& Stenholm, P. (2011). The role of creativity in opportunity search and business idea creation. Education+ Training, 53(8/9), 659- 672. https://doi.org/10.1108/00400911111185008

Murnieks, C. Y., Mosakowski, E., \& Cardon, M. S. (2011). Pathways of fire: An empirical look at entrepreneurial passion. Frontiers of entrepreneurship research, 31(4), 2.

Nabi, G., \& Li-án, F. (2011). Graduate entrepreneurship in the developing world: Intentions, education and development. Education + Training, 53, 325-334. https://doi.org/10.1108/00400911111147668

Padilla-Meléndez, A., Fernández-Gámez, M. A., \& Molina-Gómez, J. (2014). Feeling the risks: effects of the development of emotional competences with outdoor training on the entrepreneurial intent of university students. International Entrepreneurship and Management Journal, 10(4), 861-884. https://doi.org/10.1007/s11365-014-0310-y

Papaleontiou-Louca, E., Varnava-Marouchou, D., Mihai, S., \& Konis, E. (2014). Teaching for Creativity in Universities. Journal of Education and Human Development, 3(4), 131-154. https://doi.org/10.15640/jehd.v3n4a13

Perttula, K. (2003). The POW factor: Understanding passion for one's work. Paper presented at the annual meeting of the Academy of Management, Seattle, Washington.

Peterman, N. E., \& Kennedy, J. (2003). Enterprise education: Influencing students' perceptions of entrepreneurship. Entrepreneurship Theory and Practice, 28, 129- 144. https://doi.org/10.1046/j.1540-6520.2003.00035.x

Pittaway, L., Hannon, P., Gibb, A., \& Thompson, J. (2009b). Assessment practice in enterprise education. International Journal of Entrepreneurial Behaviour \& Research, 15(1), 71-93. https://doi.org/10.1108/13552550910934468

Prakash, D., Jain, S., \& Chauhan, K. (2015). Entrepreneurial intensity in relation to presence of entrepreneurship development cell: A study of institutes offering professional courses in national capital region Delhi, India. The International Journal of Management Education, 13(1), 95-105. https://doi.org/10.1016/j.ijme.2015.01.004

Preacher, K. J., \& Hayes, A. F. (2008). Asymptotic and resampling strategies for assessing and comparing indirect effects in multiple mediator models. Behavior research methods, 40(3), 879-891. https://doi.org/10.3758/BRM.40.3.879

Riaz, Q., Farrukh, M., Rehman, S. U., \& Ishaque, A. (2016). Religion and entrepreneurial intentions: an empirical investigation. International Journal of Advanced and Applied Sciences, 3(9), 31-36. https://doi.org/10.21833/ijaas.2016.09.006

Robinson, P., \& Haynes, M. (1991). Entrepreneurship education in America's major universities. Entrepreneurship Theory and Practice, 15(3), 41-52. https://doi.org/10.1177/104225879101500304 
Runco, M. A. (2004). Everyone Has Creative Potential. In R. J. Sternberg, E. L. Grigorenko \& J. L. Singer (Eds.), Creativity: From potential to realization (pp. 21-30). Washington, DC: American Psychological Association. https://doi.org/10.1037/10692-002

Shahzad, I. A., Farrukh, M., Kanwal, N., \& Sakib, A. (2018). Decision-making participation eulogizes probability of behavioral output; job satisfaction, and employee performance (evidence from professionals having low and high levels of perceived organizational support). World Journal of Entrepreneurship, Management and Sustainable Development. https://doi.org/10.1108/WJEMSD-01-2018-0006

Shapero, A., \& Sokol, L. (1982). The social dimensions of entrepreneurship. Encyclopedia of entrepreneurship, 72-90.

Smilor, R. W. (1997). Entrepreneurship: Reflections on a subversive activity. Journal of Business Venturing, 12, 341-346. https://doi.org/10.1016/S0883-9026(97)00008-6

Solesvik, M. Z., Westhead, P., Kolvereid, L., \& Matlay, H. (2012). Student intentions to become self-employed: The Ukrainian context. Journal of Small Business and Enterprise Development, 19, 441-460. https://doi.org/10.1108/14626001211250153

Souitaris, V., Zerbinati, S., \& Al-Laham, A. (2007b). Do entrepreneurship programmes raise entrepreneurial intention of science and engineering students? The effect of learning, inspiration and resources. Journal of Business Venturing, 22, 566-591. https://doi.org/10.1016/j.jbusvent.2006.05.002

Tepper, S. J., \& Kuh, G. D. (2010). Let's get serious about cultivating creativity. Chronicle of Higher Education, 58, B13-B14.

Vallerand, R. J., Blanchard, C., Mageau, G. A., Koestner, R., Ratelle, C., Léonard, M., Marsolais, J., (2003). Les passions de l'âme: On obsessive and harmonious passion. Journal $\begin{array}{lllll}\text { of Personality } \quad \text { and } & \text { Social } & \text { Psychology, } & \text { 85, }\end{array}$ https://doi.org/10.1037/0022-3514.85.4.756

Vallerand, R. J., Salvy, S.-J., Mageau, G. A., Elliot, A. J., Denis, P. L., Grouzet, F. M. E., \& Blanchard, C. (2007). On the role of passion in performance. Journal of Personality, 75, 505-534. https://doi.org/10.1111/j.1467-6494.2007.00447.x

Vesalainen, J., \& Pihkala, T. (1999). Motivation structure and entrepreneurial intentions. In P. Reynolds, W.D. Bygrave, S. Manigart, C.M. Mason, G.D. Meyer, H.J. Sapienza \& K. J. Shaver (Eds.), Frontiers of entrepreneurship research (pp. 73-87). Wellesley, MA Babson College Press.

Wang, W., Lu, W., \& Millington, J. K. (2011). Determinants of entrepreneurial intention among college students in China and USA. Journal of Global Entrepreneurship Research, $1(1), 35-44$.

Ward, T. B. (2004). Cognition, creativity, and entrepreneurship. Journal of Business Venturing, 19, 173-188. https://doi.org/10.1016/S0883-9026(03)00005-3 
Wilson, F., Kickul, J., \& Marlino, D. (2007). Gender, entrepreneurial self efficacy, and entrepreneurial career intentions: Implications for entrepreneurship education. Entrepreneurship Theory and Practice, 31, 387-406. https://doi.org/10.1111/j.1540-6520.2007.00179.x

Yusof, S. W. M., Jabar, J., Murad, M. A., \& Ortega, R. T. (2017). Exploring the cultural determinants of entrepreneurial success: The case of Malaysia. INTERNATIONAL JOURNAL OF ADVANCED AND APPLIED SCIENCES, 4(12), 287-297. https://doi.org/10.21833/ijaas.2017.012.048

Zampetakis, L. A., Gotsi, M., Andriopoulos, C., \& Moustakis, V. (2011). Creativity and entrepreneurial intention in young people: Empirical insights from business school students. The International Journal of Entrepreneurship and Innovation, 12, 189-199. https://doi.org/10.5367/ijei.2011.0037

Zhang, J., \& Duan, Y. (2010). The impact of different types of market orientation on product innovation performance: Evidence from Chinese manufacturers. Management Decision, 48, 849-867. https://doi.org/10.1108/00251741011053433 